\title{
Lameness supposedly due to trauma-induced neuroma formation
}

\author{
M.R. van der Harst and Astrid B.M. Rijkenhuizen \\ Faculty of Veterinary Medicine, Department of Equine Sciences, Utrecht University
}

\begin{abstract}
Summary
Neuroma formation in the horse is a well-documented complication following neurectomy. In other species neuroma formation has also been reported after traumatic transection of nerves. In this report a case of probable neuroma formation in a horse as a result of a traumatic wound and its successful surgical treatment are described. It is suggested that any wound with nerve damage in the horse should be treated quickly and adequately and that sufficient box rest should be given in order to prevent the formation of painful posttraumatic neuromas.
\end{abstract}

Keywords:

equine, neuroma, traumatic wound

\begin{abstract}
Vermutlich durch Trauma-induzierte Neurom-Bildung verursachte Lahmheit bei einem Pferd
Als Komplikation nach Neurektomien ist die Neurom-Bildung beim Pferd gut dokumentiert. Auch bei anderen Spezies ist das Auftreten von Neuromen nach Transsektion von Nerven bekannt. Ein 4-jähriges weibliches Holländisches Springpferd wurde mit einer mittelgradigen Lahmheit (3/4) der linken Hintergliedmaße vorgestellt. Vier Monate zuvor hatte sich die Stute eine als oberflächlich eingeschätzte Verletzung im medioplantaren Kronbereich zugezogen, die nicht abgeheilt war. Das Pferd war regelmäßig an der Hand bewegt worden. Bei Vorstellung war die Wunde mit oberflächlich infiziertem Granulationsgewebe bedeckt und ohne Fistelung. Der Wundbereich war auf Palpation wie auch die passive Bewegung des Fesselgelenks extrem schmerzhaft. Klinisch und radiologisch konnten knöcherne Veränderungen in der Verletzungsregion und Erkrankungen im Hufbereich ausgeschlossen werden. Als Schmerzursache wurde eine verletzungsbedingte Neurombildung vermutet und infolgedessen die Neurektomie des N. digitalis plantaris durchgeführt. Die alte Wunde wurde gereinigt und für 10 Tage unter Verband gehalten. Die Patientin erhielt insgesamt für 7-9 Wochen Boxenruhe. Die Lahmheit verschwand und die alte Verletzungswunde heilte mit einer leicht erhabenen Narbe ab, die unter Bewegung gelegentlich noch leicht blutiges Exudat serzernierte. Es wird empfohlen, jegliche Verletzung mit möglicher Beteiligung von Nerven schnell und konsequent zu versorgen und durch ausreichende Boxenruhe ruhigzustellen, um die Bildung schmerzhafter posttraumatischer Neuromen zu verhindern.
\end{abstract}

Schlüsselwörter: Neurom, Wunde, Trauma, Pferd

\section{Introduction}

A neuroma is provoked by the transection of nerve tissue and consists of a branching mass of Schwann cells, connective tissue cells from the nerve trunk's sheath, and proliferating axons embedded in scar tissue (Evans et al., 1968). A painful neuroma will develop when nerve sprouts are incorporated in the connective tissue mass (Evans et al., 1968). Pain is the result of insufficient blood supply, lack of isolation of the regenerating nerve fibres, artificial synapses, or the presence of free fascicles (Martini and Fromm, 1989).

Although the exact frequency of occurrence of painful neuromas is not known, Turner et al (1995) mention 20-34\% as an estimate. The formation of painful neuromas in horses has been almost exclusively described as a (common) complication after surgical neurectomy, whereas in other species neuromas are not only seen after surgery. In human literature the amputation neuroma following trauma is a well-described entity (Farley, 1965; Mathews and Osterholm, 1972; Nelson, 1977; White, 1944). This report describes the clinical findings in a horse with a pro- bable neuroma, which developed after sustaining a wound, and its subsequent surgical treatment.

\section{Case}

History

A 4-year-old Dutch Warmblood mare, used for showjumping, was referred to the Department of Equine Sciences. Four months earlier the horse had been found with a wound on the left hind limb situated on the medioplantar side of the pastern, just proximal to the medial heelbulb. At that time the horse was only slightly lame and the wound appeared superficial. Radiographic examination showed no abnormalities. Box rest was prescribed with 20 minutes handwalking every day for 2 weeks. Initially the horse recovered well. However, after two months the lameness worsened and the practising veterinary surgeon was consulted again. The region of the wound was swollen and warm, 
and the wound was covered with purulent exsudate. Radiographic examination showed soft tissue swelling, but no bony changes. Treatment with antibiotics was started. Again, box rest with daily handwalking was prescribed. As the lameness did not improve, the horse was referred to the university clinic.

\section{Clinical findings and surgical management}

On admission the horse showed a 3/4 supporting limb lameness of the left hind limb (Stashak, 1987). A transverse laceration, $7 \mathrm{~cm}$ long, was present on the medioplantar side of the pastern, just proximal to the medial heelbulb. The limb was slightly swollen from the hoof to the midregion of the metatarsus. No distension of the fetlock joint was present. The wound was covered with moist granulation tissue, which protruded slightly above the skin edges. There were no signs of a fistula. Passive movement of the fetlock joint was extremely painful and the area just proximal to the wound was excessively pressuresensitive.

Examination of the hoof revealed no abnormalities. Radiographs of the distal phalanges and metatarsus (dorsoplantar and lateromedial views) revealed only a soft tissue swelling.

Based on the clinical and radiographical findings the most probable diagnosis was a neuroma. This suspected neuroma was confirmed to be the cause of the lameness by blocking the plantar digital nerve, just distal to the fetlock joint and proximal to the supposed neuroma, which rendered the horse almost sound. It was decided to perform a neurectomy of the plantar digital nerve just proximal to the neuroma.

Pre-operatively a wet disinfectant' bandage was applied for 2 days to prepare the wound for surgery.

After premedication with romifidine hydrochloride ${ }^{2}(0.08-0.10$ $\mathrm{mg} / \mathrm{kg}$ body weight i.v.) and induction with ketamine ${ }^{3}$ and $\mathrm{mi}-$ dazolam $^{4}$, general anaesthesia was maintained with oxygen and halothane ${ }^{5}$. The horse was positioned in left lateral recumbency. After routine preparation and draping, a $4 \mathrm{~cm}$ incision in proximodistal direction was made, just distal to the fetlock joint over the medial plantar digital nerve. The nerve was carefully dissected free and a 3-4 cm long section of the nerve was removed. The subcutis was reapposed with a simple continuous layer (1 USP Polyglactin 9106) and the skin was closed with simple interrupted sutures (0 USP Polyamide $6^{7}$ ).

As the traumatic wound had a clean and viable aspect with only slightly protruding granulation tissue, it was decided to let the wound heal by second intention and to leave the granulation tissue in place. A pressure bandage was applied for 10 days.

The skin sutures were removed after 10 days, after which ultraviolet radiation treatment was started to promote healing of the traumatic wound by second intention.

\footnotetext{
1 Halamid-d ${ }^{\circledR}$, Veip desinfectantia bv, Wijk bij Duurstede, The Netherlands.

${ }^{2}$ Sedive ${ }^{\circledR}$, Boehringer Ingelheim, Alkmaar, The Netherlands.

${ }^{3}$ Narketan $10^{\circledR}$, Chassot, Vught, The Netherlands.

${ }^{4}$ Dormicum ${ }^{\circledast}$, Roche, Mijdrecht, The Netherlands.

${ }^{5}$ Halothaan ${ }^{\circledR}$, Albic, Maassluis, The Netherlands.

${ }^{6}$ Vicryl${ }^{\circledR}$, Ethicon, Norderstedt, Germany.

7 Ethilon ${ }^{\circledR}$, Ethicon, Norderstedt, Germany.
}

The horse was discharged from the hospital 20 days after surgery and an additional 4-6 week period of box rest was prescribed.

\section{Outcome}

The horse recovered well during the prescribed period of box rest. The operation wound healed by primary intention and the traumatic wound healed with a slightly protruding scar. The horse was sound at a walk. After the box rest period, the horse was walked for 10 minutes per day for a month and then training was gradually resumed.

Four months after surgery the horse was sound and performed as before. The scar tissue of the original traumatic wound was still a little active, which occasionally resulted in the production of haemorrhagic exsudate during exercise. Palpation of the scar tissue or the area just proximal to the original wound did not elicit a pain reaction. Skin sensibility was normal proximal to the surgical wound and absent on the medial heelbulb and the medial side of the coronary band. Skin sensibility of the lateral heelbulb and the lateral side of the coronary band was comparable to that of the contralateral limb.

Surgical correction of the scar tissue was not deemed necessary.

\section{Discussion}

The formation of a neuroma can be provoked by a number of factors including wound infection, foreign bodies, blood clots, irritation of the wound by movement, ischaemia, and scar tissue (Mathews and Osterholm, 1972; Schebitz and Vollmerhaus, 1979). Many of these factors are commonly present in a traumatic wound. However, to our knowledge, the formation of a neuroma in horses following severing of a nerve due to trauma has not been previously described. This may be due to the fact that most nerves are well protected by surrounding structures and that nerves are fairly elastic.

Several factors could explain why a painful neuroma could develop in this specific case, 4 months after trauma. Obviously, nerve damage had occurred due to the original traumatic incident. The wound was left untreated and subsequently became infected. An important factor may have been that the horse was walked every day. This will have increased the risk of wound contamination but, more importantly, the constant movement will have delayed wound-healing, leading to a constant irritation of the nerve ends. In the scar tissue circulation will have been impaired, leading to local ischaemia (Mathews and Osterholm, 1972). Thus, virtually all factors, which are known to be able to induce the formation of a painful neuroma, may have been present.

With respect to treatment, it was decided to create a new surgical wound just proximal to the old traumatic wound and not to approach the neuroma through the latter. Although the wound had a clean and viable appearance after the application of a disinfectant bandage for 2 days, there were several reasons for creating a new wound. Firstly, total removal of the neuroma including all its sprouts would have been difficult, especially as it was em- 
bedded in scar tissue. Secondly, despite the viable appearance it was considered that the chance of the formation of a second neuroma would be greater than when creating a fresh wound. As a result of this approach, the neuroma was not removed, and histological confirmation of the diagnosis was therefore not possible. However, the history and the clinical signs are so suggestive that there was no doubt about the final diagnosis. The outcome after surgical treatment, which resulted in a complete loss of pain of the soft tissue swelling, further confirmed the diagnosis.

It can be concluded that, whenever nerve damage is suspected in a traumatic wound, neuroma formation should be recognised as a potential complication. To prevent this, it is important to try to achieve primary healing of the wound, avoiding all circumstances, which may affect the process of wound healing. Therefore, careful cleaning of the wound, ligation of any large bleeding vessels and removal of blood clots is important. To prevent infection, adequate antibiotic treatment should be provided. A period of rest is absolutely essential for satisfactory wound healing in this kind of wound. In many cases this is best achieved by immobilisation of the limb.

\section{References}

Evans, L.H., J.B. Campbell, B. Pinner-Poole and J. Jenny (1968): Prevention of painful neuromas in horses. J. Am. Vet. Med. Ass. 153, 313-324
Farley, H.H. (1965): Painful stump neuroma. Minnesota Medicine, 347350

Martini, A. and B. Fromm (1989): A new operation for the prevention and treatment of amputation neuromas. J. Bone Joint Surg. 71-B 3, 379-382

Mathews, G.J. and J.L. Osterholm (1972): Painful traumatic neuromas. Surg. Clin. North America 51, 1313-1324

Nelson, A.W. (1977): The painful neuroma: the regenerating axon versus the epineural sheath. J. Surg. Res. 23, 215-221

Schebitz, H. and B. Vollmerhaus (1979): Podotrochleose- Komplikationen nach Neurectomie der Rami palmares. Berl. Münchn. Tierärtzl. Wschr. 92, 289-293

Stashak, T.S. (1987): Diagnosis of lameness. In: Adams' lameness in horses, $4^{\text {th }}$ edn., Philadelphia, Lea \& Febiger, 106

Turner, A.S., C.W. Trotter and B.E. Powers (1995): Evaluation of tissue adhesive to contain axonal regeneration in horses. Vet. Surg. 24, 308-314

White, J.C. (1944): Pain after amputation and its treatment. J.A.M.A. $124,1030-1035$

\section{Acknowledgements}

The authors would like to thank dr. P.R. van Weeren for his help in preparing the manuscript.

M.R. van der Harst DVM

Astrid B.M. Rijkenhuizen DVM, PhD, Dipl. ECVS, Dipl. RNVA

Faculty of Veterinary Medicine

Department of Equine Sciences

Yalelaan 12

3584 CM Utrecht

The Netherlands 